\title{
血液透析患者の腎性貧血に対する クエン酸第二鉄水和物の有効性の検討
}



キーワード：クエン酸第二鉄水和物, 鉄剤, TSAT, Hb 濃度, ESA 抵抗性 〈要旨〉

【目的】クエン酸第二鉄水和物投与開始時に鉄剂投与を中止し，腎性貧血に対する有効性について検討した.【対象】 95 名の血液透析患者のうち, 選択基準を満たした 45 名.【方法】クエン酸第二鉄水和物 $1,500 \mathrm{mg} /$ 日投与時に静注・ 経口鉄剤投与を中止し, 鉄関連検査値, ダルベポエチン $\alpha$ (DA) 投与量, ESA 抵抗性について検討した. 【結果】対 象患者全体の検討では，フェリチン值，TSAT に有意な変化を認めず， Hb 濃度が有意に上昇した。 DA 投与量も有 意に低下し，40.1％の DA 削減効果を認めた。鉄剂服用群別の検討では，静注鉄剂中止群は $50.2 \%$ ，経口鉄剂中止 群は 33.5\%のDA 削減効果を認め, ESA 抵抗性は低下した.【結語】クエン酸第二鉄水和物 $1,500 \mathrm{mg} /$ 日投与時に鉄 剂を中止することで鉄過剰を防ぎ，さらに Hb 濃度が上昇した。貧血改善効果は静注，経口鉄剤より良好であると 考えられ，クエン酸第二鉄水和物の腎性貧血に対する有効性が示唆された.

\section{Efficacy of ferric citrate hydrate in hemodialysis patients with renal ane- mia}

Takaaki Furuno ${ }^{1}$, Kaoru Miyake ${ }^{1}$, Fumie Sasaki ${ }^{1}$, Takeshi Kawaguchi ${ }^{1}$, Hiroshi Handa ${ }^{1}$, Keisuke Imai $^{1}$, Yuji Takatori ${ }^{2}$, Koutarou Fujiwara ${ }^{3}$, Hisako Fujiwara ${ }^{4}$

${ }^{1}$ Department of Pharmacy, ${ }^{2}$ Department of Nephrology, ${ }^{3}$ Department of Cardiovascular Surgery, ${ }^{4}$ Department of Dialysis, Kohsei General Hospital

Key words : ferric citrate hydrate, iron, TSAT, Hb concentration, erythropoietic resistance index $\langle$ Abstract〉

【Objective】In order to examine the efficacy of ferric citrate hydrate against renal anemia, we discontinued the administration of iron when ferric citrate hydrate was administered.【Subjects】 Among 95 hemodialysis patients at our hospital between June 2014 and February 2015, 45 patients (31 males and 14 females) who met the entry criteria were enrolled in this study.【Methods】 We discontinued iron administration to patients who were receiving intravenous or oral iron administration while ferric citrate hydrate $1,500 \mathrm{mg} /$ day was administered, and investigated iron metabolism markers, darbepoetin $\alpha$ (DA) doses and erythropoietic resistance index.【Results】 Examination of all the subject patients showed that there were no significant changes in serum ferritin levels and TSAT levels. However, $\mathrm{Hb}$ concentration significantly increased. DA doses significantly decreased and $40.1 \% \mathrm{DA}$ reduction effect was observed. Examination of each iron dose group showed that the DA reduction effect was $50.2 \%$ in the intravenous iron discontinuation group and $33.5 \%$ in the oral iron discontinuation group, and the erythropoietic resistance index decreased.【Conclusion】 We were able to prevent excessive iron intake by discontinuing iron administration when ferric citrate hydrate $1,500 \mathrm{mg} /$ day was administered. Furthermore, $\mathrm{Hb}$ con-

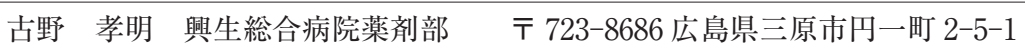

Takaaki Furuno Tel : 0848-63-5500 Fax : 0848-62-0600

〔受付日：2015 年 4 月 10 日, 受理日：2015 年 7 月 10 日〕 
centration increased. Ferric citrate hydrate was more effective in improving anemia than intravenous or oral iron administration. Thus, the efficacy of ferric citrate hydrate against renal anemia was demonstrated.

\section{緒 言}

2008 年の日本透析医学会「慢性腎臓病患者における 腎性貧血治療のガイドライン」1)では，鉄の評価と補充 療法に関してTSAT $20 \%$ 以下と血清フェリチン值 100 $\mathrm{ng} / \mathrm{mL}$ 以下の両方を満たす場合を開始基準としてい る. 透析患者はダイアライザへの残血と採血検査など により容易に鉄欠そ状態に陥りやすい。そのため腎性 貧血治療において, 赤血球造血刺激因子製剂 (erythropoiesis stimulating agent：ESA）の効果を発揮するた めには鉄欠乏を診断し，適切な鉄補充を行う必要があ る.しかしながら, 2012 年末の JSDT の統計調査 ${ }^{2}$ に よると, TSAT 20\%未満かつ血清フェリチン值 100 $\mathrm{ng} / \mathrm{mL}$ 未満の患者は $28.9 \%$ と報告され，約 3 割の透析 患者は鉄欠乏であることが明らかとなった。一方，鉄 剤の過剩投与は感染症リスクの増大, 心・血管系合併 症リスクの進展などが報告されている ${ }^{3,4)}$ ，現在，鉄補 充に関して明確な安全限界は示されておらず，鉄過剩 をきたさないために最小限の鉄補充を行う必要がある.

2014 年 5 月, カルシウム非含有でリン吸着能が高い 新規リン吸着剂としてクエン酸第二鉄水和物が上市さ れた．有効成分の鉄が一部体内で吸収され，血清フェ リチン值や $\mathrm{Hb}$ などの鉄関連検査值の変動が報告され ており5，鉄欠乏に陥りやすい透析患者において鉄補 充の役割も期待されている. しかしながら，鉄補充と して静注および経口鉄剤が使用され，クエン酸第二鉄 水和物と併用により鉄過㮃が懸念されている.

そのためわれわれはクエン酸第二鉄水和物投与開始 時に静注および経口鉄剂投与中の患者に対し鉄剤投与 を中止し，6か月にわたり鉄関連検査值と ESA 製剤の ダルベポエチン $\alpha$ （DA）投与量および ESA 抵抗性 (erythropoietic resistance index：ESAI）を調査し, 腎性貧血に対する有効性について検討した。

\section{I. 対象}

対象は 2014 年 6 月〜 2015 年 2 月の興生総合病院外 来維持透析患者 95 例のうち，以下の基準を満たす患 者.

1）20 歳以上，90 歳以下

2）透析導入後 6 か月以上経過している患者

3） 2014 年 6 月時点でリン吸着剤を服用中の患者ま
たはリン吸着剤を服用していない患者で血清リン值が $6.0 \mathrm{mg} / \mathrm{dL}$ 以上の患者

4）医師により治療参加の同意を得た患者 除外基準は,

1）過去 6 か月以内に輸血の既往のある患者

2）鉄剂による副作用歴がある患者

3）医師が不適切と判断した患者

本研究は, 前向き観察研究として社会医療法人里仁 会の倫理委員会で承認を得た。

\section{II. 方 法}

\section{1. 投与薬物}

対象患者に対し既存のリン吸着剤から切り替えまた は新規投与としてクエン酸第二鉄水和物 $1,500 \mathrm{mg} /$ 日 を 3 分割で朝昼夕食後に経口投与した。各種リン吸着 剂からの切り替えは宮崎ら ${ }^{5)}$ の報告, Daugirdas $ら^{6)}$ の 報告をもとに炭酸カルシウム $1,500 \mathrm{mg}$, 塩酸セベラ マー 2,250 mg, 炭酸ランタン $750 \mathrm{mg}$ をクエン酸第二 鉄水和物 $1,500 \mathrm{mg}$ に切り替えた。また，静注鉄剤の含 糖酸化鉄 $40 \mathrm{mg} /$ 日を週 1 回, 経口鉄剂のクエン酸第一 鉄ナトリウム $50 \mathrm{mg}$ /日を 1 分割で投与中の患者は鉄 剂を中止した. ESA 製剤の増減は腎性貧血治療のガイ ドライン ${ }^{1)}$ に従い，医師の判断で行った。

\section{2. 評価項目}

血液検査はクエン酸第二鉄水和物投与前および 1 , $2 ， 3 ， 4 ， 5 ， 6$ か月後に血液透析開始直前の静脈側穿 刺部位より採血し測定した。評価項目は血清フェリチ ン值, トランスフェリン飽和度（TSAT), Hb 濃度, 週あたりのDA 投与量, ESAI，血清リン值，血清 PTH 值とした。ただし，血清 PTH 值の測定は投与前， 3 か 月後, 6 か月後とした. ESAI は DA 投与量を透析後体 重（kg）と $\mathrm{Hb}$ 濃度（g/dL）で割った值である $\mathrm{ESA}$ $\mu \mathrm{g} / \mathrm{kg} / \mathrm{g} / \mathrm{dL} /$ 週とした。その他，切り替えによる有害 事象, ESAの反応別に検討を行った.

\section{3. 統計処理}

経時的変化は非正規性を確認し Bonfferoni 補正（求 めた $\mathrm{p}$ 值を 6 倍, 血清 PTH 值の $\mathrm{p}$ 值は 2 倍とした) に よるWilcoxon 符号付順位検定を行った．欠損值処理 の方法として個々の解析において必要なデー夕に久損 值のない症例で解析した。 3 群間の比率については Fisher の正確検定， 3 群間の比較は一元配置分散分析 もしくは Kruskal-Wallis 検定を行い，有意差を認めた 
項目は Tukey 法もしくは Steel-Dwass 法にて多重比 較を行った．投与前と投与後 6 か月の比較は対応のあ る $t$-検定もしくはWilcoxon 符号付順位検定を行った. 統計処理は EZR を用い7)，すべての分析において， $\mathrm{p}<0.05$ を有意とした．表記はすべて平均值 \pm 標準偏 差で示した。

\section{III. 結果}

\section{1. 患者背景}

基準を満たした 45 名の患者を解析対象とした。患者 背景を表 1 ，鉄剂服用群別の患者背景を表 2 に示す. 鉄荗服用群別の比較では, $\mathrm{DA}$ 投与量, $\mathrm{Hb}$ 濃度, 血清 リン值に有意な差は認めなかった。一方，TSAT 值は 経口鉄剤中止群と比較して鉄剤なし群および静注鉄剂 中止群で有意に低值であった。血清フェリチン值は鉄 剂なし群と比較して静注鉄剤中止群で有意に高值で あった。観察期間の投与量変更は, 増量 $(2,250 \mathrm{mg} /$ 日）が投与 4 か月後に 2 例，投与 5 か月後に 1 例，減 量（500〜 750 mg/日） が投与 1 か月後に 1 例，投与 6

\section{表 1 対象患者全例の背景}

\begin{tabular}{lc}
\hline $\mathrm{n}$ & 45 \\
性別（男性/女性） & $31 / 14$ \\
年齢(歳) & $60.3 \pm 14.3$ \\
糖尿病歴あり (名) & 24 \\
維持透析期間 (年) & $8.4 \pm 7.2$ \\
$\mathrm{DA}$ 投与量 $(\mu \mathrm{g} /$ 週 $)$ & $19.6 \pm 12.3$ \\
$\mathrm{Hb}$ 濃度 $(\mathrm{g} / \mathrm{dL})$ & $10.0 \pm 0.9$ \\
血清リン值 $(\mathrm{mg} / \mathrm{dL})$ & $5.4 \pm 1.3$ \\
$\mathrm{TSAT}(\%)$ & $26.0 \pm 14.7$ \\
血清フェリチン值 $(\mathrm{ng} / \mathrm{mL})$ & $58.1 \pm 45.6$ \\
血清 PTH $(\mathrm{pg} / \mathrm{mL})$ & $221.7 \pm 136.6$ \\
$\mathrm{ESAI}(\mu \mathrm{g} / \mathrm{kg} / \mathrm{g} / \mathrm{dL} /$ 週 $)$ & $0.038 \pm 0.028$ \\
\hline
\end{tabular}

か月後に 1 例であった.

\section{2. 対象患者全例による検討}

血清フェリチン值および TSAT 值は観察期間内に 有意な差を認めなかった（図 $1 A, B) . H b$ 濃度は投与 1 か月後から有意に上昇し, 投与前 $10.0 \pm 0.9 \mathrm{~g} / \mathrm{dL}$ か ら投与 3 か月後 $11.0 \pm 1.4 \mathrm{~g} / \mathrm{dL}$ と有意な上昇が認めら れ，以降低下傾向を示した（図 2A）。週あたりの DA 投与量は投与前 $19.6 \pm 12.3 \mu \mathrm{g}$ から投与 6 か月後 $11.6 \pm$ $10.7 \mu \mathrm{g}$ と有意に減少した（図 2B）。ESAI は投与前

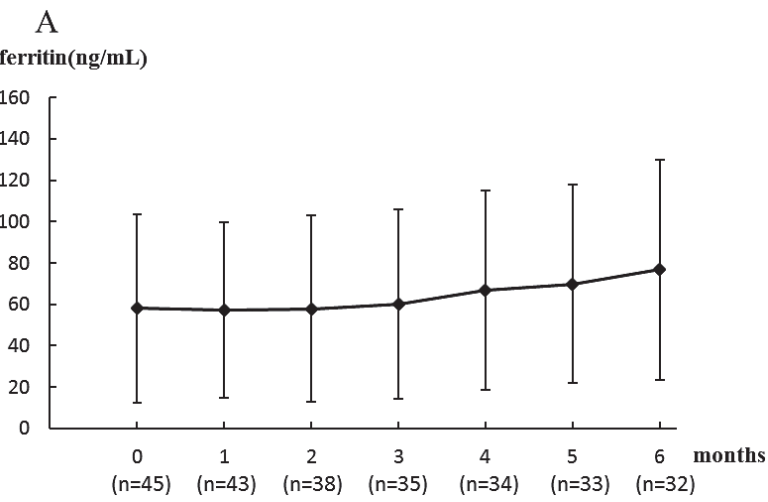

B

TSAT(\%)

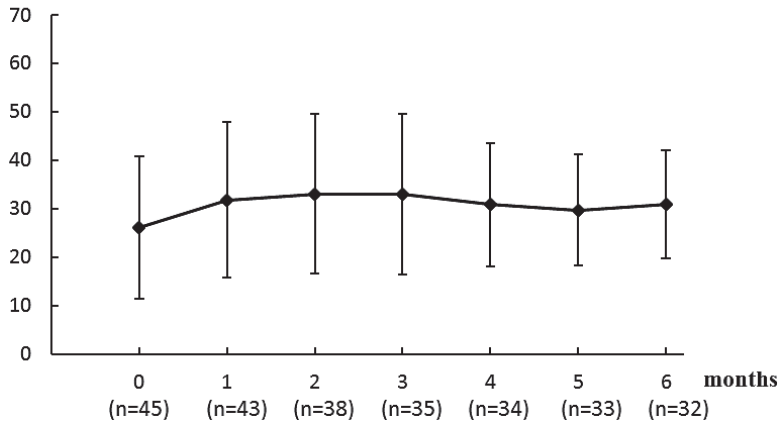

図 1 クエン酸第二鉄水和物投与後の血清フェリチン値 mean $\pm \mathrm{SD}$

\section{表 2 鉄剂服用群別の患者背景}

\begin{tabular}{|c|c|c|c|c|}
\hline & 鉄剂なし群 & 静注鉄剂中止群 & 経口鉄剂中止群 & $\mathrm{p}$ \\
\hline $\mathrm{n}$ & 12 & 19 & 14 & \\
\hline 性別 (男性/女性) a) & $9 / 3$ & $13 / 6$ & $9 / 5$ & 0.92 \\
\hline 糖尿病歴あり $(\text { 名 })^{\mathrm{a})}$ & 8 & 9 & 7 & 0.60 \\
\hline 年齢（歳) $)^{b}$ & $61.6 \pm 13.9$ & $57.0 \pm 12.3$ & $63.6 \pm 16.9$ & 0.40 \\
\hline 維持透析期間 (年) ${ }^{\mathrm{c})}$ & $8.0 \pm 7.6$ & $6.6 \pm 3.8$ & $11.3 \pm 9.5$ & 0.67 \\
\hline $\mathrm{DA}$ 投与量 $(\mu \mathrm{g} / \text { 週 })^{\mathrm{c})}$ & $16.7 \pm 12.9$ & $21.1 \pm 12.3$ & $20.0 \pm 12.2$ & 0.61 \\
\hline $\mathrm{Hb}$ 濃度 $(\mathrm{g} / \mathrm{dL})^{\mathrm{b})}$ & $9.6 \pm 0.7$ & $10.2 \pm 1.1$ & $10.0 \pm 0.7$ & 0.27 \\
\hline 血清リン值 $(\mathrm{mg} / \mathrm{dL})^{\mathrm{c})}$ & $5.8 \pm 0.9$ & $5.3 \pm 1.6$ & $5.3 \pm 1.1$ & 0.24 \\
\hline $\operatorname{TSAT}(\%)^{\mathrm{c})}$ & $19.3 \pm 9.4 * *$ & $22.7 \pm 13.6^{*}$ & $36.2 \pm 15.3$ & $<0.01$ \\
\hline 血清フェリチン值 $(\mathrm{ng} / \mathrm{mL})^{\mathrm{c})}$ & $35.1 \pm 36.2$ & $76.9 \pm 44.3^{\dagger \dagger}$ & $52.3 \pm 46.7$ & $<0.01$ \\
\hline 血清 PTH $(\mathrm{pg} / \mathrm{mL})^{\mathrm{c})}$ & $221.0 \pm 150.6$ & $219.0 \pm 137.4$ & $225.5 \pm 133.9$ & 0.98 \\
\hline
\end{tabular}



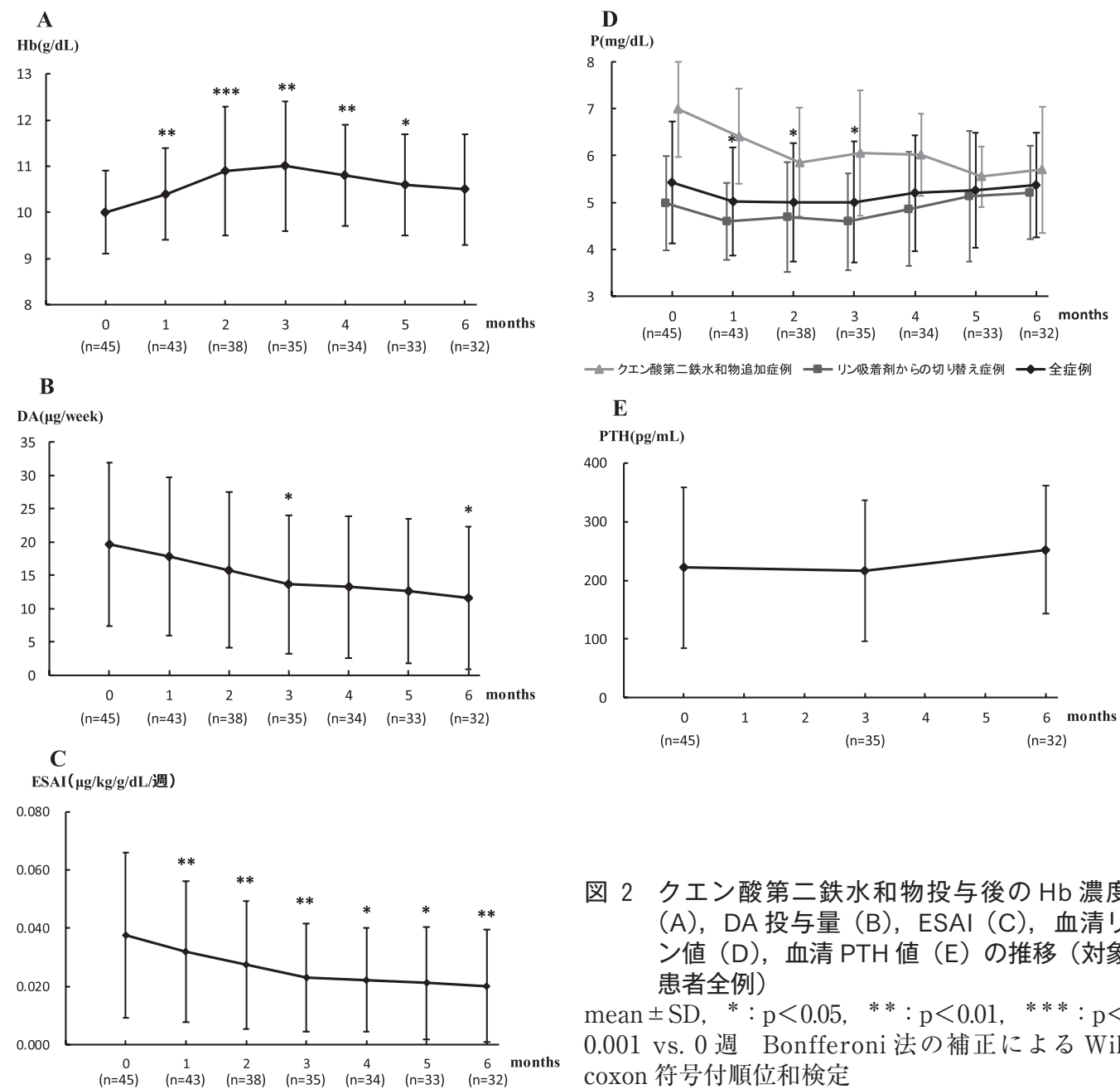

図 2 クエン酸第二鉄水和物投与後の $\mathrm{Hb}$ 濃度 (A)，DA 投与量 (B)，ESAI (C)，血清リ ン値（D), 血清 PTH 値（E）の推移（対象 患者全例)

mean $\pm \mathrm{SD}, * \mathrm{p}<0.05, \quad * *: \mathrm{p}<0.01, * * *: \mathrm{p}<$ 0.001 vs. 0 週 Bonfferoni 法の補正によるWilcoxon 符号付順位和検定

$0.038 \pm 0.028 \mu \mathrm{g} / \mathrm{kg} / \mathrm{g} / \mathrm{dL} /$ 週から投与 6 か月後 $0.020 \pm$ $0.019 \mu \mathrm{g} / \mathrm{kg} / \mathrm{g} / \mathrm{dL} /$ 週と有意に低下し, ESAI の改善が 認められた（図 2C）。血清リン值は追加症例（10名） で低下傾向を示した（図 2D）。血清 PTH 值は有意な 差を認めなかった（図 2E）。

\section{3. 鉄剂服用群別による検討}

鉄剂なし群 (12 名), 静注鉄剂中止群 (19 名), 経口 鉄剂中止群（14名）の 3 群に分けて解析した。血清 フェリチン值は 3 群間ともに有意な変化を認めなかっ たが，上昇傾向を示した（図 3A）。TSAT 值は鉄剤な し群で投与 1 か月後に有意な上昇を認めた（図 3B）. $\mathrm{Hb}$ 濃度は鉄剂なし群で投与 1 か月後および投与 6 か 月後，静注鉄剂中止群で投与 2 か月後に有意な上昇が 認められた（図 4A）。週あたりの DA 投与量は 3 群間 ともに有意な変化を認めなかったが, 低下傾向を示し た (図 4B). 平均 DA 削減率は投与 6 か月後に鉄剤な 乙群 $36.5 \%$, 静注鉄剂中止群 $50.2 \%$, 経口鉄剤中止群 $33.5 \%$ であった (図 4B). ESAI は 3 群とも有意な差を 認めなかったが，低下傾向を示した（図 4C).

\section{4. 有害事象の検討}

胃腸障害として下痢 8 名 (17.8\%), 便秘 3 名 (6.7\%), 胃部不快感 3 名 $(6.7 \%)$, 食欲減退 3 名 $(6.7 \%)$ であっ た。そのうち下痢 5 名, 胃部不快感 1 名, 食欲減退 2 名がクエン酸第二鉄水和物の投与を中止した。その他 の中止理由は $\mathrm{Hb}$ 増加 2 名, 発疹 1 名, 掻痒感 1 名, 内服拒否 1 名であった。治療継続率は全体で $71 \%$, 鉄 剂服用群別では鉄剤なし群 $75 \%$, 静注鉄剂中止群 $58 \%$ ，経口鉄中止群 86\%であった。

\section{ESA の反応別検討（表 3）}

対象患者 45 名のうち 6 か月間継続できた 32 名を DA 投与量変化より DA 減量群 17 例, DA 不変群 11 例, DA 増量群 4 例の 3 群に分けて比較検討した。患者背 景では年齢, 性別, 糖尿病歴, 鉄剂服用群に有意な差 は認めなかった。投与前の 3 群間で比較すると, DA 投与量, 血清フェリチン值, TSAT 值, Hb 濃度, ESAI に有意な差は認めなかった。 各群での投与前と 6 か月 後の比較では DA 減量群では Hb 濃度は有意に上昇し, ESAI は有意に低下した。また有意差は認めなかった が，TSAT 值が上昇傾向であった。 DA 不変群ではい 


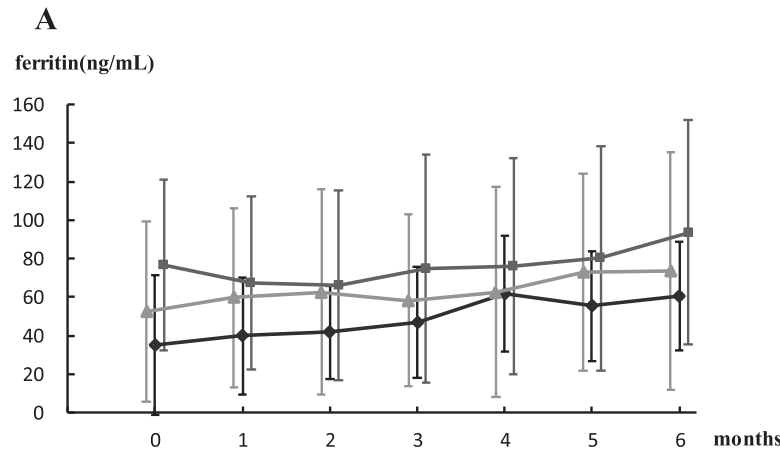

\section{B}

TSAT(\%)

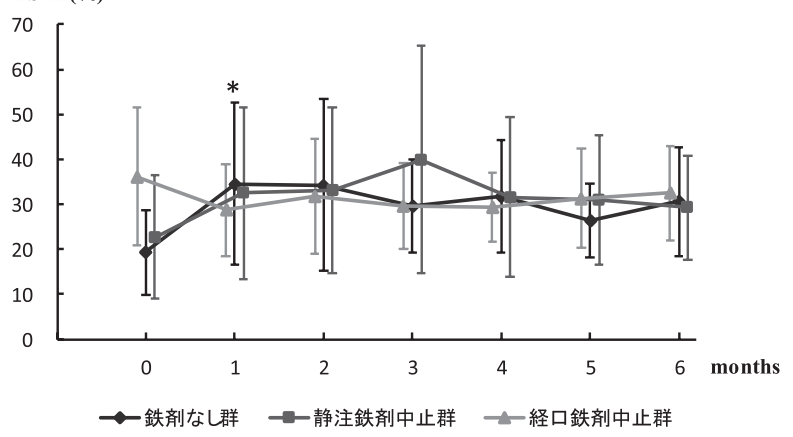

図 3 クエン酸第二鉄水和物投与後の血清フェリチン值 (A), TSAT 值（B）の推移（鉄剂服用群別）

mean $\pm \mathrm{SD}, \quad *: \mathrm{p}<0.05, * *: \mathrm{p}<0.01, * * *: \mathrm{p}<0.001$ vs. 0 週 Bonfferoni 法の補正によるWilcoxon 符号付順位和検 定

ずれの值も有意な差は認めなかった。一方, DA 増量 群ではESAI は有意に上昇した。またTSAT 值は低下 傾向であった.

\section{IV. 考 察}

わが国では，世界のほかの国と比較し，静注鉄剤の 投与量割合および投与量が少なく，血清フェリチン值 も低く維持されている ${ }^{8)}$. 血清フェリチン值 $100 \mathrm{ng} /$ $\mathrm{mL}$ 以上の群は, $100 \mathrm{ng} / \mathrm{mL}$ 未満の群に比べて死亡リ スクが高いこと ${ }^{9)}$,さらに静注鉄剂の使用量の増加に 伴い心血管イベント発生率・死亡率が有意に上昇する ことが報告されている10)。そのため透析患者の貧血治 療における鉄補充には注意する必要があると考えられ る.

クエン酸第二鉄水和物は，鉄を主成分とする新規の リン吸着剂として，リン低下作用だけでなく，鉄補充 にも期待される薬羭である. Yokoyama ら ${ }^{11)}$ はクエン 酸第二鉄水和物投与後, 静注鉄剂の投与量は減少し, 終了時に静注鉄剤を $90 \%$ 以上減量したと報告してい る.今回われわれは鉄剤の過剰投与を避けるため鉄剤 併用を中止し，6か月にわたり鉄関連検査值，DA 投
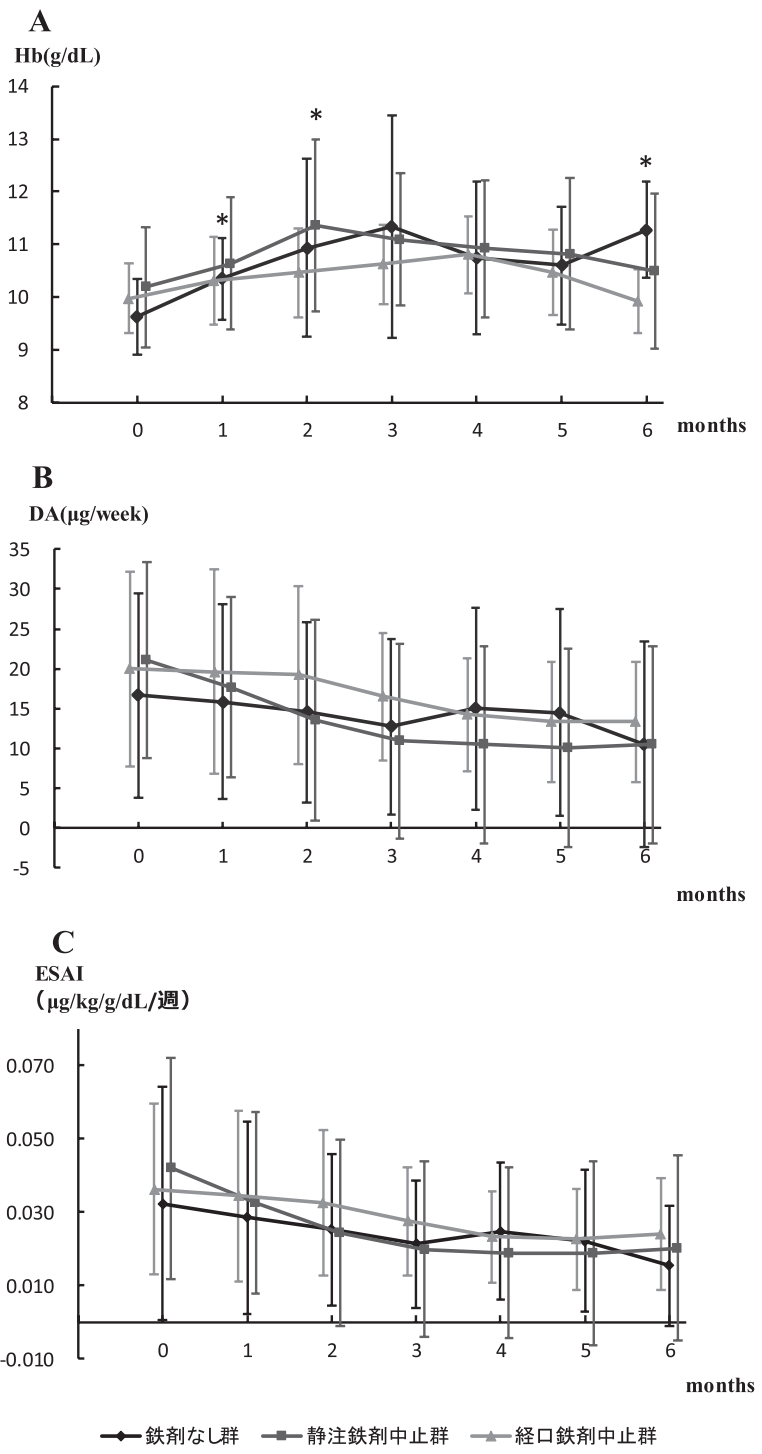

図 4 クエン酸第二鉄水和物投与後の $\mathrm{Hb}$ 濃度 $(\mathrm{A}), \mathrm{DA}$ 投与量 (B), ESAI (C) の推移 (鉄剂服用群別)

mean $\pm \mathrm{SD}, \quad *: \mathrm{p}<0.05, \quad * *: \mathrm{p}<0.01, * * *: \mathrm{p}<0.001$ vs. 0 週 Bonfferoni 法の補正によるWilcoxon 符号付順位 和検定

与量, ESAI を調査し, 血液透析患者の腎性貧血に対 するクエン酸第二鉄水和物の有効性について検討した.

対象患者全例の検討では血清リン值は追加症例およ び切り替え症例ともに有意な変化を認めなかったが, 追加症例は低下傾向を示した。 この結果よりリン吸着 剤の切り替えは既報のとおりであると考えられた。 血 清フェリチン值および TSAT 值は有意な変化を認め なかったが, $\mathrm{Hb}$ 濃度は有意な上昇が認められた。さ らに週あたりの DA 投与量も有意に低下し，腎性貧血 に対する有効性が認められた。 血液透析患者を対象と した第 III相長期投与試験 (13 か月間) では TSAT 值, $\mathrm{Hb}$ 濃度, 血清フェリチン值は投与 4 か月まで上昇傾 向が認められ, それ以降, TSAT 值は定常化し, Hb 
表 3 ESA の反応別検討

\begin{tabular}{|c|c|c|c|c|c|}
\hline & & $\mathrm{DA}$ 減量群 & DA 不変群 & $\mathrm{DA}$ 増量群 & $\mathrm{p}$ \\
\hline \multicolumn{2}{|l|}{$\mathrm{n}$} & 17 & 11 & 4 & \\
\hline \multicolumn{2}{|l|}{ 年齢a) } & $61.4 \pm 15.2$ & $58.3 \pm 13.8$ & $52.3 \pm 20.2$ & 0.55 \\
\hline \multicolumn{2}{|l|}{ 性別 (男性/女性) ${ }^{b)}$} & $12 / 5$ & $8 / 3$ & $2 / 2$ & 0.75 \\
\hline \multicolumn{2}{|l|}{ 糖尿病歴ありb) } & 11 & 5 & 2 & 0.61 \\
\hline \multicolumn{6}{|l|}{ 鉄剂服用群別b) } \\
\hline \multicolumn{2}{|l|}{ 鉄剂なし群 } & 6 & 2 & 1 & 0.61 \\
\hline \multicolumn{2}{|l|}{ 静注鉄剂中止群 } & 7 & 3 & 1 & \\
\hline \multicolumn{2}{|l|}{ 経口鉄剂中止群 } & 4 & 6 & 2 & \\
\hline \multirow{2}{*}{$\begin{array}{l}\text { DA 投与量c) } \\
(\mu \mathrm{g} / \text { 週 })\end{array}$} & 投与前 & $22.6 \pm 11.3$ & $15.0 \pm 10.7$ & $13.8 \pm 11.1$ & 0.19 \\
\hline & 6 か月後 & $6.8 \pm 7.5^{\dagger+\dagger}$ & $15.0 \pm 10.7^{*}$ & $22.5 \pm 12.6^{*, \dagger \dagger}$ & 0.01 \\
\hline \multirow{2}{*}{$\begin{array}{l}\text { フェリチン值 }{ }^{\mathrm{c})} \\
(\mathrm{ng} / \mathrm{mL})\end{array}$} & 投与前 & $58.6 \pm 50.6$ & $72.5 \pm 56.3$ & $54.1 \pm 18.0$ & 0.62 \\
\hline & 6 か月後 & $83.6 \pm 56.3$ & $69.5 \pm 53.4$ & $67.9 \pm 48.8$ & 0.53 \\
\hline \multirow{2}{*}{$\begin{array}{l}\left.\text { TSAT 值 }{ }^{\mathrm{C}}\right) \\
(\%)\end{array}$} & 投与前 & $26.6 \pm 16.7$ & $30.9 \pm 10.3$ & $37.8 \pm 22.0$ & 0.32 \\
\hline & 6 か月後 & $33.4 \pm 11.2$ & $30.5 \pm 10.2$ & $21.2 \pm 9.3$ & 0.14 \\
\hline \multirow{2}{*}{$\begin{array}{l}\mathrm{Hb} \text { 濃度 }{ }^{\mathrm{a})} \\
(\mathrm{g} / \mathrm{dL})\end{array}$} & 投与前 & $9.9 \pm 1.0$ & $9.9 \pm 0.8$ & $9.9 \pm 0.8$ & 1.00 \\
\hline & 6 か月後 & $11.0 \pm 1.2^{\dagger}$ & $10.0 \pm 0.9$ & $9.8 \pm 0.4$ & 0.04 \\
\hline \multirow{2}{*}{$\begin{array}{l}\mathrm{ESAI}^{\mathrm{c})} \\
(\mu \mathrm{g} / \mathrm{kg} / \mathrm{g} / \mathrm{dL} / \text { 週 })\end{array}$} & 投与前 & $0.046 \pm 0.029$ & $0.027 \pm 0.024$ & $0.021 \pm 0.012$ & 0.10 \\
\hline & 6 か月後 & $0.012 \pm 0.014^{\dagger \dagger \dagger}$ & $0.026 \pm 0.023$ & $0.037 \pm 0.014^{*, \dagger}$ & 0.01 \\
\hline
\end{tabular}

濃度は投与 7 か月後まで低下，血清フェリチン值は投 与 7 か月後まで上昇した. また, 投与量別の解析では, クエン酸第二鉄水和物 $\leqq 1,500 \mathrm{mg} /$ 日投与で各平均值 が TSAT 值は $20 \%$ から $30 \%$ 程度に上昇し, 血清フェ リチン值は $200 \mathrm{ng} / \mathrm{mL}$ を超えない範囲の上昇であっ たと報告している11,12)．われわれの検討でも同様の傾 向が認められた. TSAT 值は投与 3 か月後まで上昇傾 向を示し, それ以降定常化した. $\mathrm{Hb}$ 濃度は投与 3 か 月後まで上昇し，それ以降低下傾向を示した。血清 フェリチン值は投与 6 か月後まで上昇傾向を示した.

また，投与前と比較し投与 6 か月後で血清フェリチン 值は $58.1 \pm 45.6 \mathrm{ng} / \mathrm{mL}$ から $76.8 \pm 53.3 \mathrm{ng} / \mathrm{mL}$, TSAT 值は $26.0 \pm 14.7 \%$ から $30.9 \pm 11.1 \%$ の上昇であった。第 III相長期投与試験では鉄剤併用患者も含まれるため, 鉄剂の併用を中止することでTSAT 值および血清 フェリチン值の上昇は低くなる可能性が考えられた。

今回われわれの検討でクエン酸第二鉄水和物 1,500 $\mathrm{mg} /$ 日投与時に鉄剂併用を中止することで血清フェリ チン值およびTSAT 值の上昇を低くし，鉄過剰投与を 回避できる可能性が示唆された.さらにHb濃度上昇, ESAI の改善を認めたため, 鉄剤服用群別について詳 細に検討した.

鉄剂なし群では，Hb 濃度および TSAT 值は投与 1 か月後に有意な上昇が認められた。宮崎ら ${ }^{5)}$ は $\mathrm{Hb}$ 濃度 上昇に関して投与前の血清フェリチン值の低さがもっ とも影響の大きい因子であったと報告している．投与
前の血清フェリチン值およびTSAT值はほかの 2 群と 比較し低值であり，鉄開始基準を満たす患者が 5 名存 在した。そのため, 吸収された鉄が急速に造血に利用 されたため投与初期に貧血改善効果を認めたと考えら れた。静注鉄剂中止群では, $\mathrm{Hb}$ 濃度は投与 2 か月後 に有意に上昇し，投与 6 か月後の平均 DA 削減率は $50.2 \%$ と高值であった. TSAT值は投与前 $22.7 \pm 13.6 \%$ から投与 3 か月後 $39.9 \pm 25.3 \%$ と上昇傾向を認めた. 三馬ら ${ }^{13)}$ は ESA 治療維持期における鉄剂の投与方法 について検討し, 静注鉄剂群と比較し経口鉄剤群で Ht 值, $\mathrm{Hb}$ 濃度, 血清鉄值がもっとも増加し, 経口投与 により鉄過剩をきたさず貧血改善がより円滑に行われ たと報告している。また，静注鉄剤は経口鉄剤よりも 酸化ストレスや細胞障害を多く惹起することが示唆さ $れ^{5)}$ ，それら炎症により鉄利用を阻害することで ESA 低反応性をまねく可能性があると考えられた。そのた め, 静注鉄剤からクエン酸第二鉄水和物投与に切り替 えることで炎症低下による ESAI 改善効果, 経口投与 による有効な鉄利用などにより貧血改善効果を認めた と考えられた．経口鉄剤中止群では， Hb 濃度は投与 4 か月まで緩やかな上昇傾向を認め, 平均 DA 削減率は $33.5 \%$ であった. クエン酸第二鉄水和物の鉄吸収は, 食品添加物のクエン酸第二鉄を単回経口投与したとき の体内への吸収量から算出している ${ }^{14)}$. しかしながら クエン酸第二鉄水和物の比表面積はクエン酸第二鉄よ り大きく溶解速度が速いこと, また, 経口鉄剂は鉄欠 
そ患者では吸収されやすいことが報告されているた め ${ }^{15)}$, 従来の報告より鉄吸収率は高いと考えられた。 われわれの検討でTSAT 值は約 $30 \%$ を維持し，血清 フェリチン值も上昇傾向を認めたことからクエン酸第 二鉄水和物 $1,500 \mathrm{mg}$ /日投与のほうが鉄吸収は良好で あると考えられた。また, 経口鉄剤 1 日 1 回投与とク エン酸第二鉄水和物 3 分割投与では, 投与回数が増え ることにより鉄の血中濃度が維持されやすいため貧血 改善が良好であったと思われる。しかしながら，経口 鉄剂とクエン酸第二鉄水和物の鉄吸収, 鉄の血中濃度 に関して比較検討した報告はなく，今後の検討課題で あると考えられる。

クエン酸第二鉄水和物の副作用は胃腸障害（19\%） が多く，主に下痢の頻度 $(10.1 \%)$ が高いことが報告 されている12). 今回の検討では, それよりも胃腸障害 の発現率は $37.8 \%$ と高く，そのうち下痢の頻度は $17.8 \%$ と高值であった。 さらに下痢による中止例が 5 名であり，下痢によって治療の継続が困難となる症例 が多く, 注意が必要と思われた。一方, 鉄剤のクエン 酸第一鉄ナトリウム，含糖酸化鉄の胃腸障害はそれぞ れ $23.8 \%, 2.2 \%$ であり，主に悪心・嘔吐が報告されて いる ${ }^{16,17)}$. 鉄剤と比ベクエン酸第二鉄水和物の胃腸障 害の発現率は高く，とくに下痢が多く認められた。一 方で鉄剂に多い悪心・嘔吐の副作用は少なく，長期投 与試験でも悪心・嘔吐の発現率は $0.6 \%$ であり，悪心・ 嘔吐による服薬中止例は報告されず18)，われわれの検 討と同様の結果であった．胃腸障害の対策として減量 することで継続できた症例も認められたため，初期投 与量について今後の検討課題であると考えられた。 ま た， $\mathrm{Hb}$ 過上昇（>13 g/dL）により投与を中止した患 者を 2 例認めた。 2 例とも DA 投与なしで目標 $\mathrm{Hb}$ 濃 度を維持している症例に認められ，TSAT 值が $7.2 \%$ から $37 \% ， 6.3 \%$ から $82.1 \%$ まで上昇した.一方，血清 フェリチン值の過上昇は認めなかった。 そのため DA 投与なしで目標 $\mathrm{Hb}$ 濃度を維持している患者に対して は過剩造血に注意する必要があると考えられた。

クエン酸第二鉄水和物の貧血改善効果予測因子検討 のため投与前と投与 6 か月後の DA 投与量を DA 減量 群, DA 不変群, DA 増量群に層別し検討した. 年歯, 性別, 糖尿病歴, 鉄剂服用群および投与前の血清フェ リチン值, TSAT 值, Hb 濃度, ESAI は 3 群に有意な 差はなく，投与前に貧血改善効果を予測することはで きなかった。しかしながら，TSAT 值は投与前と比較 し投与 6 か月後では DA 減量群で増加傾向, DA 不変 群で変化なし, DA 増量群で低下傾向を示し, ESAI は DA 減量群で有意に低下, DA 不変群で変化なし, DA
増量群で有意に増加と一定の傾向が認められた。 ESAI の予測には, 血清フェリチン值よりも TSAT 值 のほうが優れるとの報告がされており ${ }^{2)}$, これはわれ われの検討とも一致するものであった.

われわれの検討においてクエン酸第二鉄水和物 1,500 mg/日投与により良好な貧血改善効果を認めた. 一方で $\mathrm{Hb}$ 濃度が安定した投与 4 か月後から血清フェ リチン值の増加傾向が認められ，DA 減量に伴い貯蔵 鉄の利用が低下し，血清フェリチン值が増加する可能 性が考えられた。 そのため, 今後長期的な鉄関連検査 值の観察が必要と思われる。

\section{結語}

クエン酸第二鉄水和物 $1,500 \mathrm{mg}$ /日投与時に鉄剤併 用を中止することで血清フェリチン值および TSAT 值に有意な差を認めず, $\mathrm{Hb}$ 濃度が有意に上昇した。 さらに貧血改善効果は, 静注鉄剂の含糖酸化鉄 40 $\mathrm{mg}$ /日を週 1 回投与, 経口鉄剤のクエン酸第一鉄ナト リウム $50 \mathrm{mg}$ /日 1 分割投与より良好と考えられ, クエ ン酸第二鉄水和物の腎性貧血に対する有効性が示唆さ れた。

\section{文献}

1）日本透析医学会. 2008 年版日本透析医学会慢性腎臓病 患者における腎性貧血治療のガイドライン．透析会誌 2008； 41：661-716.

2）日本透析医学会統計調査委員会. 図説わが国の慢性透 析療法の現況 2012 年 12 月 31 日現在. 東京：日本透析 医学会, 2013.

3) Tielemans CL, Lenclud CM, Wens R, Collart FE, Dratwa M. Critical role of iron overload in the increased susceptibility of haemodialysis patients to bacterial infections. Beneficial effects of desferrioxamine. Nephrol Dial Transplant 1989; 4: 883-7.

4) Drüeke $T$, Witko-Sarsat V, Massy $Z$, et al. Iron therapy, advanced oxidation protein products, and carotid artery intima-media thickness in end-stage renal disease. Circulation 2002; 106: 2212-7.

5）宮崎章, 松尾明, 飯田聡夫, 他. 新規高リン血症治療 薬クエン酸第二鉄水和物（リオナ ${ }^{\circledR}$ 錠 $250 \mathrm{mg}$ ）の薬理 学的特性と臨床試験成績. 日薬理誌 2014；144：294304.

6) Daugirdas JT, Finn WF, Emmett M, et al. The phosphate binder equivalent dose. Semin Dial 2011; 24: 41-9.

7) Kanda Y. Investigation of the freely available easyto-use software 'EZR' for medical statistics. Bone Marrow Transplantation 2013; 48: 452-8. 
8) Bailie GR, Larkina M, Goodkin DA, et al. Variation in intravenous iron use internationally and over time. Nephrol Dial Transplant 2013; 28: 2570-9.

9) Hasuike Y, Nonoguchi H, Tokuyama M, et al. Serum ferritin predicts prognosis in hemodialysis patients: the Nishinomiya study. Clin Exp Nephrol 2010; 14: 349-55.

10) Kuo KL, Hung SC, Lin YP, et al. Intravenous ferric chloride hexahydrate supplementation induced endothelial dysfunction and increased cardiovascular risk among hemodialysis patients. PLoS One 2012; 7 : e50295.

11) Yokoyama K, Akiba T, Fukagawa M, et al. Longterm safety and efficacy of a novel iron-containing phosphate binder, JTT-751, in patients receiving hemodialysis. J Ren Nutr 2014; 24: 261-7.

12）鳥居薬品株式会社. リオナ ${ }^{\circledR}$ 錠 $250 \mathrm{mg}$ 医薬品インタ ビューフォーム。 2014 年 5 月（改訂第 2 版）, 2014.
13）三馬省二，吉田克法，佐々木憲二，他. 腎性貧血に対 するエリスロポイエチン製剤治療維持期における鉄剤 の投与方法に関する多施設共同研究. 臨床と研究 1995; 72: 230-4.

14) Dietzfelbinger $\mathrm{H}$. Bioavailability of bi- and trivalent oral iron preparations. Investigations of iron absorption by postabsorption serum iron concentrations curves. Arzneimittelforschung 1987; 37: 107-12.

15）齋藤宏. 鉄代謝異常の臨床. 大阪：医薬ジャーナル社, 1999; 56.

16）エーザイ株式会社. フェロミア ${ }^{\circledR}$ 錠 $50 \mathrm{mg}$ 医薬品イン タビューフォーム．2014 年 6 月改訂, 2014.

17）日医工株式会社. フェジン ${ }^{\circledR}$ 静注 $40 \mathrm{mg}$ 医薬品インタ ビューフォーム。2014 年 10 月改訂, 2014.

18）松村謙二. 鉄, アルミニウム, ランタン化合物と高リ ン血症治療. YAKUGAKU ZASSHI 2015；135：5459. 